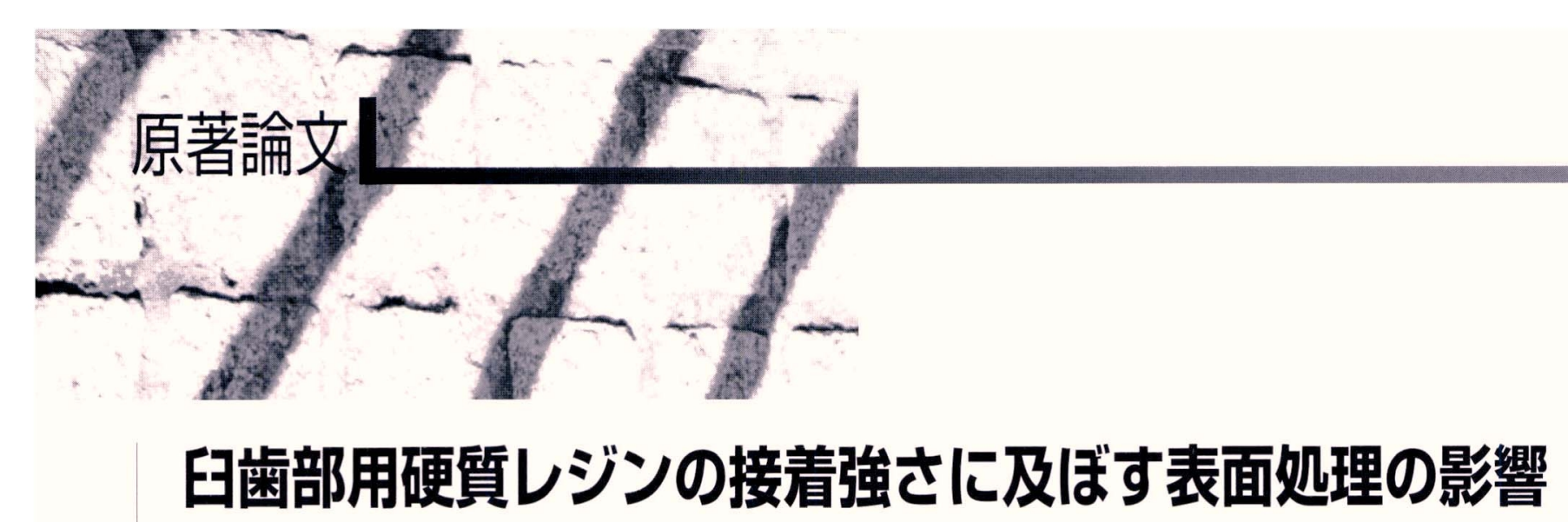

新里 朗, 高橋英登, 横塚繁雄

\title{
Effect of surface treatment on Bond Strength of Hard Resin For Posterior Restorations
}

Akira Niisato, Hideto Takahashi, Shigeo Yokozuka

For appropriate functioning of head rasin for posterior restorations in the oral cavity, not only the mechanical strength of the restoration material itself but also its fitness and bonding to the abutment tooth, i.e., unification with the tooth, is indispensable. One of the factors associated with bonding is surface treatment of the bonding is surface of the restoration material. To the clarify the effects of surface treatment on the bond strength of head rasin for posterior restorations, we performed the combination of sandblast treatment, silane treatment, and heat treatment of the bonding surface before bonding with reasin cement. After storage of the samples at $37^{\circ} \mathrm{C}$ for 24 hours followed by 3,000 thermal cycles $\left(4 \sim 60^{\circ} \mathrm{C}\right)$, bond strength was measured. Bond strength improved after sandblast treatment performed in combination with silane treatment and heat treatment of the bonding surface. Even after thermal cycles, bondstrength only slightly decreased. Therefore, the combination of sandblast treatment, silane treatment and heat treatment of the bonding surface. Even after thermal cycles, bond strength only slightly decreased. Therefore, the combination of sandblast treatment, silane treatment, and heat treatment of the bonding surface head rasin for posterior restorations is useful for improving bond strength and bonding durability.

曰僯部用硬質レジンが口腔内で機能するには，修復物本来の機械的強度だけでなく，支 台歯との適合性と接着，すなわち支台歯との一体化が不可欠な要件となる。この接着に関 倸している因子の一つに被着面の表面処理があげられる.

そこで本研究では, 日歯部用硬質レジンの接着強さに及ぼす表面处理の影響老明らかに することを目的として, 被着面にサンドブラスト処理, シラン处理, 加熱处理を行いレジ ンセメントにて接着した際の各表面処理条件について, $37^{\circ} \mathrm{C} 24$ 時間保存後とサーマルサ イクル $\left(4^{\circ} \mathrm{C} \sim 60^{\circ} \mathrm{C}, 3,000\right.$ 回) を加えた後の接着強さを比較検討した.

被着面に対してサンドブラスト処理, シラン処理, 加熱処理を行うと, 接着強さの向上 が認められた。また，サーマルサイクル後でも接着強さの減少は少なかった。したがって, 曰歯部用硬質レジンの被着面に対しサンドブラスト処理, シラン処理と加熱処理の組み合 わせは，接着強さの向上ならびに接着耐久性の向上に有効であった。

Key words：ハイブリッドセラミックス hybrid ceramics, 接着性レジンセメント adhesive resin, シランカップリング剂 silane coupling agent, 接着 adhesive strength，接着耐久性 adhesive durability 


\section{緒 言}

臼歯部用硬質レジン（ハイブリッドセラミックス）は， 前歯部から大臼歯部にまで幅広く応用できる歯冠色修復材 料として注目され臨床応用されている1,2). その機械的性 質は，これまでの硬質レジンと比べ格段に向上している3 が，ジャケットクラウンなど，単体で使用する場合は，接 着性レジンセメントを用いて支台歯との一体化を図ること が不可欠な要件となる ${ }^{4)}$.

われわれは，接着強さに及ぼす因子として被着面の表面 処理方法に着目し，コンポジット系レジンセメントとの接 着強さに及ぼす表面処理の影響を明らかにした5).

今回は，性質の異なるMMA系レジンセメントについて 実験を行い，その影響を検討した。

\section{材料および方法}

\section{1. 実験材料}

表 1 に本研究で使用した材料の製品名, メーカー, 色 調, Lot.No, 略号を示す.

\section{2. 実験計画}

【実験 1】ではスーパーボンドC＆B（サンメディカル） (以下, SB と略す) によるエステニア デンティン（クラレ） (以下, ES と略す) の接着強さに及ぼす表面処理の影響を検 討するため, 表己に示した因子と水準について二元配置 による要因配置実験法を採用した。すなわち，サンドブラ スト処理（因子A）として2水準, シランカップリング剤 による処理（以下，シラン処理と略す）（因子B）として 3 水準を設定した。各条件について, 繰り返し数は 5 回とし た。

【実験2】ではSBによる ES の接着耐久性に及ぼす表面処 理の影響を検討するため, 表2の因子と水準で定めた条 件の試験片について $4{ }^{\circ} \mathrm{C}$ と $60^{\circ} \mathrm{C}$ 水中浸漬を各 1 分間行 うサーマルサイクルを 3,000 回行い, その後に接着強さを 測定した。各条件について，繰り返し数は5回とした。

\section{3. 試験片の製作}

\section{1）被着体の製作およびサンドブラスト処理}

常温重合レジン（ユニファーストIIクリア，GC）を $10 \times$ $10 \times 20 \mathrm{~mm}, 10 \times 10 \times 10 \mathrm{~mm}$ の角柱に加工し, $10 \times 10 \times$ $20 \mathrm{~mm}$ の角柱の $10 \times 20 \mathrm{~mm}$ 面と $10 \times 10 \times 10 \mathrm{~mm}$ の角柱の 一面に内径 $7 \mathrm{~mm}$, 深さ $2.5 \mathrm{~mm}$ の円柱状の窩洞を形成し, 最 深部に脱離防止のアンダーカットを付与した。 その窩洞に ESを約 $0.5 \mathrm{~mm}$ ずつ 5 回に分けて積層充填した. 各層ごとに
表 1 実験材料

\begin{tabular}{|c|c|c|c|c|c|}
\hline 材 料 & 製品名 & xーカー & 色調 & Lot.No & 略号 \\
\hline $\begin{array}{l}\text { 䶄部用硬質レジン } \\
\text { (ハイブリッドセラ } \\
\text { ミックス) }\end{array}$ & $\begin{array}{c}\text { エステニア } \\
\text { デンティン }\end{array}$ & クラレ & DA3 & $0013 A A$ & ES \\
\hline シランカップリング剤 & $\begin{array}{l}\text { ポーセレン } \\
\text { ライナーM }\end{array}$ & $\begin{array}{c}\text { サンメディ } \\
\text { カル }\end{array}$ & - & 80201 & PLM \\
\hline 接着性レジンセメント & $\begin{array}{c}\text { スーパーボン } \\
\quad \text { ドC \& B } \\
\text { (モノマー・ポ } \\
\text { リマー・キャ } \\
\text { タリスト) }\end{array}$ & $\begin{array}{c}\text { サンメディ } \\
\text { カル }\end{array}$ & $\begin{array}{l}\text { クリ } \\
\text { アー }\end{array}$ & 80402 & SB \\
\hline
\end{tabular}

表2 因子と水準

\begin{tabular}{|l|c|c|c|}
\hline \multirow{2}{*}{\multicolumn{1}{|c|}{ 子 }} & \multicolumn{3}{|c|}{ 水 準 } \\
\cline { 2 - 4 } & 1 & 2 & 3 \\
\hline A : サンドブラスト処理 & なし & あり & - \\
\hline B：シラン処理 & なし & あり & シラン処理と加熱処理 \\
\hline
\end{tabular}

光重合器（ $\alpha$-ライトII，モリ夕）を使用し 30 秒間の予備重 合を行った。また，5回目の充填時にガラス板をESに圧接 して光重合を行い被着面を製作した。最終光重合は 300 秒 行った。その後, 加熱重合器 $(\mathrm{KL}-100$, クラレ) (以下, $\mathrm{KL}-100$ と略す）を用い $110^{\circ} \mathrm{C}, 15$ 分間の加熱重合を行っ て $10 \times 10 \times 20 \mathrm{~mm}$ の被着体（以下，A被着体と略す）と， $10 \times 10 \times 10 \mathrm{~mm}$ の被着体（以下，B被着体と略す）を製作 した。また, 被着面にサンドブラスト処理を行う被着体に おいては，サンドブラスター（ハイブラスター，松風）を 用い, 平均粒径 $50 \mu \mathrm{m}$ のアルミナ粒 (ハイアルミナ, 松風) を噴射圧力 $0.147 \mathrm{MPa}\left(1.5 \mathrm{kgf} / \mathrm{cm}^{2}\right)$, 噴射距離 $20 \mathrm{~mm}$, 噴 射時間2秒間の条件で, $\mathrm{A}$ 被着体, $\mathrm{B}$ 被着体ともに処理し た.その後, $\mathrm{A}$ 被着体, $\mathrm{B}$ 被着体ともに精製水にて 15 分間 超音波洗浄を行い自然乾燥した. 次に, $\mathrm{A}$ 被着体の被着面 には，直径 $5 \mathrm{~mm}$ の穴をあけた厚さ $100 \mu$ のマスキングテー プを貼り，被着面積を規制するとともにセメントスペース を確保した。

\section{2）被着面のシラン処理および加熱処理}

【実験 1】,【実験2】においてシラン処理を行う被着体に ついては，ポーセレンライナーM（サシメディカル）（以 下, PLM と略す）のA 液, B 液を各 1 滴ずつ滴下混和した 後，A被着体ではマスキングテープにより規制された直径 $5 \mathrm{~mm}$ の ES の被着面に, B 被着体には直径 $7 \mathrm{~mm}$ の $\mathrm{ES}$ 全面に 塗布し 10 秒間放置後, 弱いエアブローを行った.さらに, 加熱処理を行う被着体については, シラン処理後に炉内温 


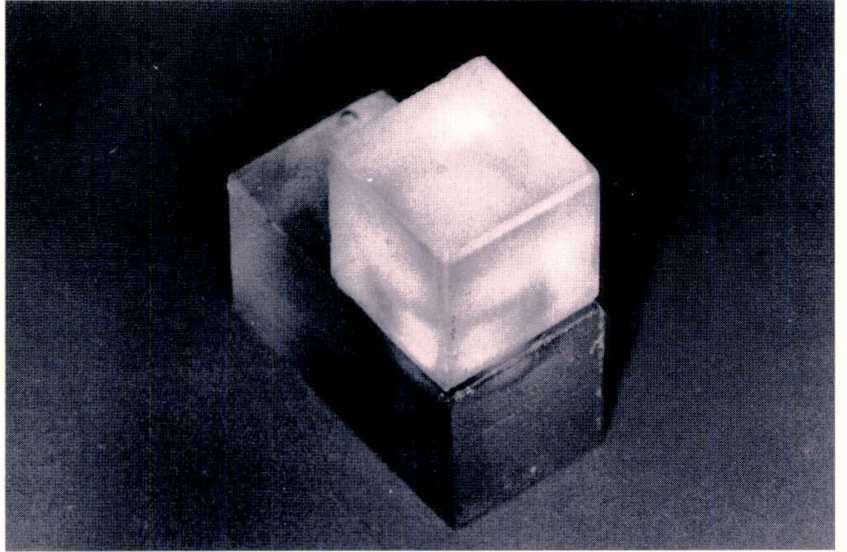

図 1 接着後の試験片

度 $110^{\circ} \mathrm{C}$ に設定した $\mathrm{KL}-100 て ゙ 1$ 分間の加熱処理を行った。

\section{3）接着操作}

【実験 1】，【実験2】では，メーカー指示に従いSBに付属 のダッペンデッシュにモノマー液を4滴，キャタリストを 1 滴の割合で滴下，摚拌した後，ポリマーを小カップ1杯入 れ混和後に両被着面に塗布し被着体どうしの圧接を行い, 定荷重試験機（セイキ）を用いて直ちに荷重 $15 \mathrm{kgf}$ ，荷重 時間 15 分の条件で荷重を加えた。荷重を加えてすぐに接着 部からの余剩 SB 除去した。接着を終えた試験片は直ちに $37^{\circ} \mathrm{C}$ の恒温槽内で 24 時間水中浸漬し, 【実験 1】の試験片 とした。【実験 $2 】 て ゙ は ， 37^{\circ} \mathrm{C}$ 水中に 24 時間浸漬後，サー マルサイクル試験を行った。図１に接着を終えた試験片の 1 例を示す。

\section{4. 接着強さの測定法}

接着強さの測定には，長谷部と中村 ${ }^{6}$ が使用した圧縮せ ん断接着強さ測定装置を用いた。試験片を圧縮せん断接着 強さ測定装置に装着後，この装置を材料試験機（サーボパ ルサーEHF-FD1，島津）に固定し，ローディングスピード $0.5 \mathrm{~mm} / \mathrm{min}$ でせん断荷重を加えた。

\section{結 果}

\section{1.【実験 1】の測定結果}

図2に【実験1】の測定結果を, 表 3 に接着強さの二元 配置分散分析表を示す，表4に接着強さの平均值の差の検 定（t検定）の結果老示す。

\section{2.【実験 2】の測定結果}

図3に【実験2】の測定結果を, 表5に接着強さの二元 配置分散分析表を示す. 表 6 に接着強さの平均値の差の検 定（t検定）の結果を示す。

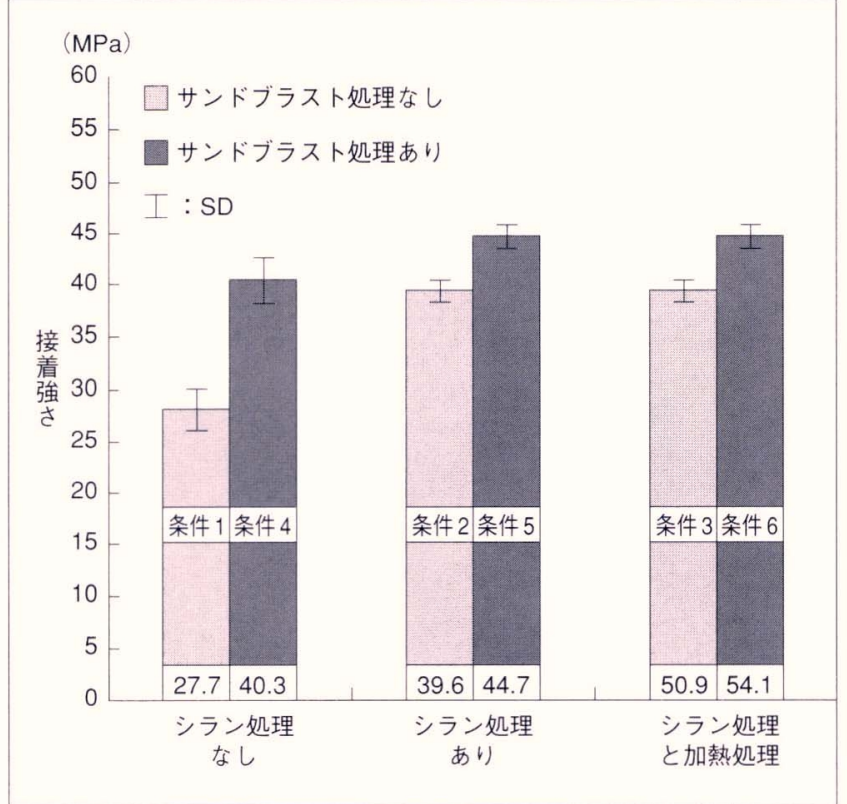

図2 $37^{\circ} \mathrm{C} 24$ 時間後のSBによるES の接着強さに及ぼす表面処 理の影響

表 3 【実験 1】の二元配置分散分析表

\begin{tabular}{|c|r|r|r|r|}
\hline \multicolumn{1}{|c|}{ 子因 } & \multicolumn{1}{c|}{ s.s } & d.f & m.s & \multicolumn{1}{c|}{ Fo } \\
\hline A : サンドブラスト処理 & 361.92 & 1 & 361.92 & $39.61^{* *}$ \\
\hline B : シラン処理 & 1714.29 & 2 & 857.15 & $93.80^{* *}$ \\
\hline A $\times$ B & 125.60 & 2 & 62.80 & $6.87^{* *}$ \\
\hline$e$ & 219.31 & 24 & 9.14 & \\
\hline \hline$T$ & 2421.12 & 29 & & \\
\hline \hline
\end{tabular}

\section{表4 [実験 1]の接着強さの平均値の差の検定}

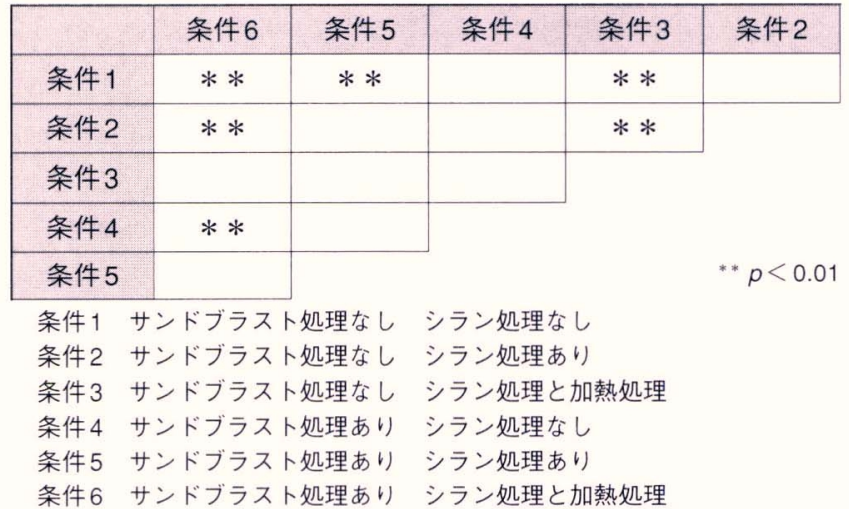




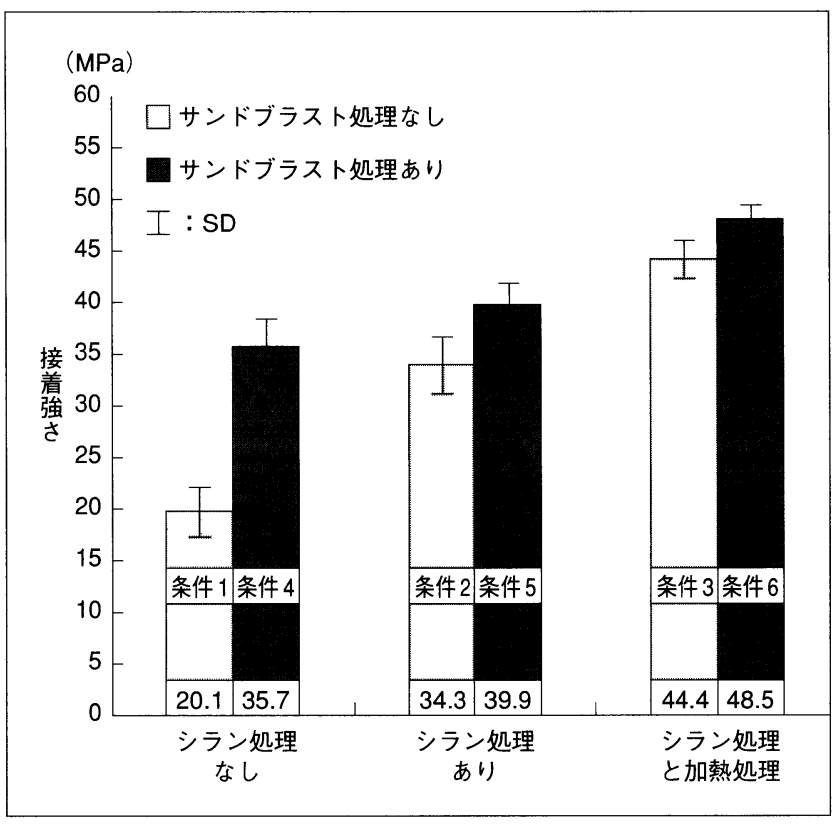

図 3 サーマルサイクル後のSBによるES の接着強さに及ぼす表 面処理の影響

表 5 【実験 2】の二元配置分散分析表

\begin{tabular}{|c|c|c|c|c|}
\hline 因 子 & S.S & d.f & $\mathrm{m} . \mathrm{s}$ & Fo \\
\hline A：サンドブラスト処理 & 1718.67 & 1 & 859.34 & $37.77^{* *}$ \\
\hline B：シラン処理 & 534.25 & 2 & 534.25 & $23.48^{* *}$ \\
\hline$A \times B$ & 192.99 & 2 & 96.50 & $4.24^{*}$ \\
\hline $\mathrm{e}$ & 546.06 & 24 & 22.75 & \\
\hline$T$ & 2991.97 & 29 & & \\
\hline
\end{tabular}

表 6 【実験 2】の接着強さの平均值の差の検定

\begin{tabular}{|c|c|c|c|c|c|}
\hline & 条件F & 条件 $\mathrm{E}$ & 条件D & 条件 C & 条件 B \\
\hline 条件 A & $* *$ & * & & * & \\
\hline \multicolumn{6}{|l|}{ 条件B } \\
\hline \multicolumn{6}{|l|}{ 条件 C } \\
\hline \multicolumn{6}{|l|}{ 条件D } \\
\hline 条件E & & & & ${ }^{*} p<0.05$ & ${ }^{* *} p<0.01$ \\
\hline \multicolumn{3}{|c|}{ 条件A サンドブラスト処理なし } & \multicolumn{3}{|c|}{ シラン処理なし } \\
\hline 条件 B & サンドブラス & 処理なし & シラン処理 & & \\
\hline 条件 C & サンドブラス & 卜処理なし & シラン処理 & 加熱処理 & \\
\hline 条件D & サンドブラス & 卜処理あり & シラン処理 & & \\
\hline 条件E & サンドブラス & 処理あり & シラン処理 & & \\
\hline 条件 F & サンドブラス & 処理あり & シラン処理 & 加熱処理 & \\
\hline
\end{tabular}

\section{考 察}

\section{1. 接着強さに及ぼす各処理の影響}

1）サンドブラスト処理が接着強さに及ぼす影響について

一般に接着力の発現機構は，まず，接着材がファンデル

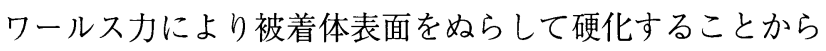
始まる7)。接着性レジンセメントの主たる接着因子はそこ に含まれる接着性モノマー，すなわちSBの場合, 4-META の親水基によるものといわれている ${ }^{8)}$.

セラミックスにサンドブラスト処理を行うとクレーマー 効果 (エキソエレクトロン放電) により被着面のぬれ性が 改善される9)。また，今井10) はセラミックスの被着面にサ ンドブラスト処理を行うと接着面積が増加するため, 接着 強さが向上すると報告している。【実験 1】においてサンド ブラスト処理のみの条件 4 がシラン処理のみの条件 1 とほ ぼ同等の接着強さを示したことは, 接着面積の増加ととも に被着面のぬれ性が改善されたため, シラン処理に匹敵す る効果が得られたと考える。

且歯部用硬質レジンの被着面に対してのサンドブラスト 処理は機械的な接着面積の増加を促すだけではなく， 臼歯 部用硬質レジンのフィラー成分を露出させる効果もあると 推測される．臼歯部用硬質レジンの超微粒子アルミナフィ ラーは，バインダー層の $67 \%$ を占めている。 そのため, サ ンドブラスト処理を行わない被着面はフィラー周囲のバイ ンダー層の面と考える. 一方, サンドブラスト処理を行っ た被着面は微粒子ランタンガラスフィラーと超微粒子アル ミナフィラーが含有量から $5: 1$ 程度の割合で露出している と推測される5 .

その結果, シラン処理の効果が顕著に現れ，未処理の条 件 1 に比較してシラン処理とサンドブラスト処理を行った 条件 5 は，有意に高い接着強さを示したものと考えられる (図3参照).

\section{2）シラン処理が接着強さに及ぼす影響について}

本研究で使用したシランカップリング剂PLMは, A 液成 分が4-METAであり, 微量の水分の存在下で4-METモノ マーとなり，シランカップリング剤を活性化すると考えら れている ${ }^{11}$.ここことから接着に際して被着面の酸性䨌囲 気が強くなり，シランカップリング剂の活性化が増強され た結果，【実験1】においてシラン処理を行った条件はシラ ン処理を行わなかった条件よりも接着強さが上回ったと思 われる。

シランカップリング剤はセラミックスの接着に有効とさ れている。しかし, 松村ら ${ }^{11)}$ はシランカップリング剤はガ ラスフィラーに対しては有効であるが，アルミナに対して 
は効果は著明ではないと報告している。このことから【実 験1】の条件 2 においてはシラン処理の効果が著明ではな く，接着面積の増加を図った条件 4 とほほ同等の接着強さ を示したことが理解できる。また，条件 2 は $39.6 \mathrm{MPa}$ の接 着強さを示したのに対し, 条件 5 は $44.7 \mathrm{MPa}$ の接着強さを 示した結果に対しても，サンドブラス卜処理によりランタ ンガラスフィラーの表面積の増加が起こり，フィラーとシ ランカップリング剂が有効に作用して化学的接着力と機械 的嵌合力の相互作用が起こったためと理解できる（図 3参 照).

\section{3）加熱処理が接着強さに及ぼす影響について}

シランカップリング剂の活性化には加熱処理が有効であ る ${ }^{10}$ 12.13). また, 高橋ら ${ }^{(4)}$ はシラン処理に加え加熱処理を行 うと, シラン処理のみの場合よりもシランカップリング剤 の活性化が増強されると報告している。【実験1】において 条件 5 と条件 6 , 条件 2 と条件 3 の接着強さを比較すると, 両者とも加熱処理を行ったほうが高い接着強さを示してい る。サンドブラスト処理により接着面積の増加が図られた のは，フィラー周囲のバインダー層も剥離されたことによ ると推測される。そその結果, 露出フィラーの表面積も増加 したため, 加熱処理によりフィラーの表面, シランカップ リング剂双方のシラノール基がシロキサン結合し強化され たため接着強さの向上につながったと推測される.

\section{4）サーマルサイクルが接着強さに及ぼす影響について}

【実験 1】と【実験2】の同一表面処理条件間で差の検定 (t検定）を行った結果，【実験2】の結果では【実験1】に 比べ接着強さの低下を認めたが，【実験1】と【実験2】間に は有意の差は認められなかった。これは $\mathrm{SB} か ゙ ~ 4{ }^{\circ} \mathrm{C} \sim 60^{\circ} \mathrm{C}$, 3,000 回程度のサーマルサイクルでは $60^{\circ} \mathrm{C}$ の水温が接着剤 層の重合反応を促進させたため 15$)$ と考える。

しかし, 本研究の【実験1】と【実験2】において条件1 と条件 $\mathrm{A}$ との比較で約 $27 \%$ 接着強さの減少が認められた. 同様に, サンドブラスト処理せずに，シラン処理を行った 場合でも，約 $13 \%$ 減少している.

同一表面処理条件間で比較を行うとサンドブラスト処理 を行った条件 4 と条件 $\mathrm{D}$, 条件 5 と条件 $\mathrm{E}$, 条件 6 と条件 $\mathrm{F}$ との間の接着強さの減少は約 $10 \%$ 程度と少量であった。こ のことは，臼歯部用硬質レジンの被着面にサンドブラスト 処理を行うと被着面積の増加が起こるだけでなく, 被着面 と SB とのぬれ性が向上して曰歯部用硬質レジン表層の微 細凹凸構造にレジンが侵入し，アンカーリングやインター ロッキングなどの作用が起こり，水分の侵入が抑制された ためと考えられる。また，条件 $\mathrm{D}$ と条件 $\mathrm{E} か ゙$ 同程度の接着 強さの減少を示したことから，茾ンドブラスト処理を行っ
た被着面に対してのシラン処理は接着強さの向上に対して 大きな効果が認められるが，接着耐久性の向上にはつなが らないと推測できる。

サンドブラスト処理, シラン処理, 加熱処理を行った条 件 $\mathrm{F}$ は, サーマルサイクル後でも $48.5 \mathrm{MPa}$ と高い接着強さ を示した。この結果から, $110^{\circ} \mathrm{C} て ゙ 1$ 分間の加熱処理によ り兒菌部用硬質レジンの被着面の最表面部に化学吸着した シランカップリング剤中のシラノール基と臼歯部用硬質レ ジンのシラノール基，あるいはSB との脱水縮合反応が促 進されただけでなく，同時にシランカップリング剂層でも 互いに縮合反応が進み，層自体の強化が起こり ${ }^{10)}$ ，水分の 侵入が抑制された結果，接着耐久性の向上につながったと 考える。

以上のことから， 臼歯部用硬質レジンの接着に際して MMA系レジンセメントを使用し，被着面にサンドブラス 卜処理とシラン処理，またシラン処理後の加熱処理を行う と, 接着強さ, 接着耐久性の向上に非常に有効であると考 える。

実際の臨床では，口腔内に装着された臼歯部用硬質レジ ンには, 直ちに機能するのに十分な接着強さが必要である. 遠山ら ${ }^{16)}$ は，接着性レジンセメントが一定の接着強さに達 するまで，パナビア EXで接着後 3 時間，スーパーボンド C \& B では 12 時間かかると報告している。また，パナビア 21 は接着後 2 時間で一定の接着強さに達するという報告も ある

接着材の耐久性も含む接着能力を最大限に発揮する以前 に，大きな負荷が修復物に加われば，その修復物は以後, 接着材の最大接着能力以下の接着強さで機能することにな る可能性がある．セメントラインが咬合面に露出するイン レーや一部被覆冠の接着に際しては, 耐摩耗性があり, 一 定の接着強さに達するまでの時間が短い接着材が適してい る. 以上のことから， 刍歯部用硬質レジンの接着に際して は，コンポジット系レジンセメントとMMA系レジンセメ ントとを症例により使い分けることが必要と考える。

\section{結 論}

臼歯部用硬質レジンの接着強さに及ほすす表面処理の影響 を明らかにするため，MMA系接着性レジンセメントとの 接着強さならびに接着耐久性を検討した結果, 以下の結論 を得た。

（1）的菌部用硬質レジンのサンドブラスト処理による表 面処理は，接着強さの向上に有効であった。

（2）自歯部用硬質レジンの被着面にシラン処理を行い接 着を行うとサンドブラスト処理なし・ありともにシラ 
ン処理の効果がほとんど認められないが，加熱処理を 行うとシラン処理の効果が双方で著明になり, シラン 処理後の加熱処理は接着強さの向上に強く影響した.

（3）臼歯部用硬質レジンの被着面に対し, サンドブラス 卜処理 · シラン処理 · 加熱処理組み合わせの表面処理 は，接着強さならびに接着耐久性の向上に有効であっ た。

\section{参考文献}

1）横塚繁雄, 高橋英登：ハイブリッドセラミックス「エス テニア」の臨床．補綴臨床, $30: 139-154,1997$.

2）高橋英登, 横塚繁雄：ハイブリッドセラミックス「エス テニア」の臨床応用．補綴臨床, $30: 667-682,1997$.

3）新谷明喜ほか：臼歯部応用を可能にした各種ハイブリッ ドセラミックスの概要. The Quintessence, 16: 691-701, 1997.

4）高橋英登：セラミックス用接着剤の臨床応用. 接着歯 学, $5: 135-144,1987$.

5）新里 朗, 高橋英登, 横塚繁雄：ハイブリッドセラミッ クスの接着強さに及ぼす表面処理の影響. 接着歯学, 18 (1) : 1-13, 2000

6）長谷部伸一, 中村健吾：接着ブリッジ用 $\mathrm{Ni}-\mathrm{Cr}-\mathrm{Co}-\mathrm{Mo}$ 合金の諸性質。歯材器, $5: 773-790,1986$.

7）増原栄一：歯科用接着性レジンの基礎と臨床 [上巻]. 第1版：23-35，クインテッセンス出版，(東京), 1982.

8）山本 秀ほか：接着性セメントの陶材に対するせん断接
着強さ一陶材の種類とその表面研削法が接着性に及ぼす 影響. 補綴誌, $30: 207-215,1986$.

9) 千葉栄一ほか：ポーセレン・ラミネートベニア修復にお ける歯質㧍よびポーセレンの表面処理の効果について一 SEMによる切断面の観察. 歯学, $81: 813-824,1993$.

10) 今井 誠：歯科用ポーセレンと接着性レジンの接着にお ける被着面処理に関する研究. 歯材器, 9:301-313, 1990.

11）松村英雄ほか：シランカップリング剂とカルボン酸系モ ノマーによる陶材・石英・アルミナの接着. 補綴誌, 31 : 1494-1498, 1997.

12）窪田敏之：歯科用接着性レジンのセラミックスに対する 接着挙動について (第2報)。歯材器, $5:$ 162-172, 1986.

13）坂本富則ほか：キャスタブルセラミックスの接着に対す る試作前処理剤（フチン酸-SnF2）プライマーの前処理 効果. 日歯保誌, $40: 1042-1052,1997$.

14）高橋純造, 岡崎正幸, 木村 博: シランカップリング剤 とは. 歯科技工, $13: 945-950,1985$.

15）宮入裕夫，高久保和夫：接着性レジンセメントのサーマ ルサイクリング。接着歯学, 4(2) : 35-44, 1996.

16）遠山佳之, 新谷明喜, 横塚繁雄 : 歯科用接着剤の接着強 さに及ぼす放置時間，放置温度および被膜厚さの影響. 接着歯学, $10: 35-64,1992$.

17）山瀬 勝, 新谷明喜, 横塚繁雄 : 接着性レジンセメント における初期接着強さの経時的变化. 歯材器, $16: 63,1997$.

別刷請求先 : 新里 朗

井荻歯科医院 